\title{
MODERNITY, POSTMODERNITY, OR CAPITALISM?
}

\author{
by ELLEN MEIKSINS WOOD
}

Since about the early 1970s, we are supposed to have been living in a new historical epoch. That epoch has been described in various ways. Some accounts emphasize cultural changes ("postmodernism"), while others focus more on economic transformations, changes in production and marketing, or in corporate and financial organization ("late capitalism," "multinational capitalism," "post-Fordism," "flexible accumulation," and so on). These descriptions have in common a preoccupation with new technologies, new forms of communication, the internet, the "information superhighway." Whatever else this new age is, it is the "information age." And whatever other factors are supposed to have figured in this epochal shift, the new technologies have been its indispensable condition. All these factors-cultural and economic, with their technological foundations-have been brought together in the concept of "postmodernity" and the proposition that in the past two or three decades, we have witnessed a historic transition from modernity to postmodernity.

This article is based on a talk, revised and enlarged, originally presented at the Socialist Scholars Conference in April of this year, for a panel organized by Monthly Review. A somewhat different version was presented a few weeks later at a conference, "The Direction of Contemporary Capitalism," at the University of Sussex in Britain.

Ellen Wood is the author of Democracy Against Capitalism. (Cambridge University Press, 1995). 


\section{From Modernity to Postmodernity}

I'd like to consider what is involved in periodizing the history of capitalism into these two major phases, modernity and postmodernity. Then I will look more closely at what seems to me wrong with the concept of modernity itself. If that concept cannot stand up, it should follow that there will not be much left of postmodernity. My main objective is to consider whether this periodization helps or hinders our understanding of capitalism.

I'd better make one thing clear at the start: of course it is important to analyze the never-ending changes in capitalism. But periodization involves more than just tracking the process of change. To propose a periodization of epochal shifts is to say something about what is essential in defining a social form like capitalism. Epochal shifts have to do with basic transformations in some essential constitutive element of the system. In other words, how we periodize capitalism depends on how we define the system in the first place. The question then is this: what do concepts like modernity and postmodernity tell us about the ways in which the people who use them understand capitalism?

I'd better explain, too, that I'm not going to be talking about the ideas of people we loosely call, or who call themselves, postmodernists. What I'm mainly concerned with here is the political economy of what some people, including Marxists like Fred Jameson and David Harvey, are calling postmodernity. So let me sketch out very briefly what they have in mind. ${ }^{1}$

According to theorists like Jameson and Harvey, modernity and postmodernity represent two different phases of capitalism. The shift from one to the other has not been a shift from capitalism to some postcapitalist or "postindustrial" era, and the basic logic of capitalist accumulation still applies. But there has nevertheless been a sea-change in the nature of capitalism, a shift from one material configuration to another, expressed in a transition from one cultural formation to a different one. 
For Jameson, for instance, postmodernity corresponds to "late capitalism" or a new multinational, "informational" and "consumerist" phase of capitalism. David Harvey, following the French Regulation School, would describe it as a transition from Fordism to flexible accumulation. A similar idea occurs in rather less nuanced form in certain theories of "disorganized capitalism." ${ }^{2}$ Postmodernity then corresponds to a phase of capitalism where mass production of standardized goods, and the forms of labor associated with it, have been replaced by flexibility: new forms of production such as "lean production," the "team concept," and "just-in-time" production; diversification of commodities for niche markets; a "flexible" labor force; mobile capital, and so on, all made possible by new informational technologies.

Corresponding to these shifts, according to these theories, there have been major cultural changes. One important way of explaining these changes, notably in Harvey's account of postmodernity, has to do with a "time-space compression," the acceleration of time and the contraction of space made possible by new technologies, in new forms of telecommunication, in fast new methods of production and marketing, new patterns of consumption, new modes of financial organization. The result has been a new cultural and intellectual configuration, labelled "postmodernism," which is said to have replaced the culture of modernism and the intellectual patterns associated with the "project of modernity."

The project of modernity, according to these accounts, had its origins in the Enlightenment, though it came to fruition in the nineteenth century. The so-called Enlightenment project is supposed to represent rationalism, technocentrism, the standardization of knowledge and production, a belief in linear progress and universal, absolute truths. Postmodernism is supposed to be a reaction to the project of modernity - though it can also be seen as rooted in modernism, in the skepticism, the sensitivity to change and contingency that was already present in the Enlightenment. Postmodernism sees the world as essentially fragmented and indeterminate, and rejects any "totalizing" discourses, any 
so-called "meta-narratives," comprehensive and universalistic theories about the world and history. It also rejects any universalistic political projects, even universalistic emancipatory projects-in other words, projects for a general "human emancipation" rather than very particular struggles against very diverse and particular oppressions.

What, then, are the implications of dividing the history of capitalism into these phases, modernity and postmodernity? The first important thing to keep in mind is that modernity is identified with capitalism. This identification may seem fairly innocuous, but I'm going to argue that it is a fundamental mistake, that the so-called project of modernity may have little to do with capitalism.

The second point is that this periodization seems to mean that there are really two major phases in capitalism and one major rupture. First, modernity seems to be everything from the eighteenth century until (probably) the 1970s (Harvey actually gives it a very precise date: 1972). You can subdivide the long phase of modernity into smaller phases (as both Jameson and Harvey do), but postmodernity seems to represent a distinctive kind of break. People may disagree about exactly when the break took place, or about its magnitude. But they seem to agree that this break is different from other epochal changes in the history of capitalism. It seems to be a break not just from some immediately preceding phase but from the whole preceding history of capitalism. At least, that seems to be the inescapable implication of tracing modernity back to the Enlightenment. So there is a major interruption in the history of capitalism somewhere between modernity and postmodernity. I'm going to argue that this interruption, or at least this way of looking at it, is problematic too.

I'll take each of these points separately: first, the concept of modernity and the identification of modernity with capitalism; and then the question of the historic rupture in the latter half of the twentieth century. I am going to argue that the theory of postmodernity that emphasizes the discontinuities within capitalism is based, explicitly or implicitly, on a theory of history that downplays the discontinuities between capitalist 
and non-capitalist societies, a theory that disguises the historical specificity of capitalism.

Modernity and the Non-History of Capitalism

Let us look first at the identification of modernity with capitalism. For that, we have to begin at the beginning, with the origin of the capitalist system. ${ }^{3}$ The main point I want to make is this: in most accounts of capitalism, there really is no beginning. Capitalism seems always to be there, somewhere; and it only needs to be released from its chains, from the fetters of feudalism (or whatever), to be allowed to grow and mature. The seeds of capitalism seem to be contained in the most primitive acts of exchange, in any form of trade or market activity. That assumption is typically connected with another one, namely that history has been an almost natural process of technological development. One way or another, capitalism more or less naturally appears when and where expanding markets and technological development reach the right level. A lot of Marxist explanations are pretty much the same-with the addition of bourgeois revolutions to help break through the fetters.

The effect of these explanations is to stress the continuity between non-capitalist and capitalist societies and to deny or disguise the specificity of capitalism. Exchange has existed since time immemorial, and it seems that the capitalist market is just more of the same. In this kind of argument, capitalism's need to revolutionize the forces of production is just an extension and an acceleration of universal and transhistorical, almost natural, tendencies. So the lineage of capitalism passes naturally from the earliest merchant through the medieval burgher to the Enlightenment bourgeois and finally to the industrial capitalist.

I think there is a similar logic in certain Marxist versions of this story, even though the narrative in more recent versions often shifts from the town to the countryside, and merchants are replaced by rural commodity producers. In these versions, petty commodity production, released from the bonds of 
feudalism, more or less naturally grows into capitalism. In other words, petty commodity producers, given half the chance, will take the capitalist road.

What gets lost in these narratives is a perception of the capitalist market as a specific social form, the product of a dramatic historical rupture. The capitalist market looks more like an opportunity than a compulsion-the imperative of accumulation and profit-maximization-that is rooted in specific social property relations and that creates its own specific drive to improve labor productivity by technical means.

I think the concept of modernity as it is commonly used belongs to this standard view of history, which takes capitalism for granted as the outcome of already existing tendencies, even natural laws, when and where they are given a chance. In the evolutionary process leading from early forms of exchange to modern industrial capitalism, modernity kicks in when these shackled economic forces, the economic rationality of the bourgeois, are liberated from traditional constraints.

So this concept of modernity belongs to a view of history that cuts across the great divide between capitalist and noncapitalist societies. It treats specifically capitalist laws of motion as if they were the universal laws of history. And it lumps together very different historical developments, capitalist and non-capitalist. At its worst, then, this view of history makes capitalism historically invisible. At the very least, it naturalizes capitalism.

It's important to notice, too, that even anti-modernism can have the same effect of naturalizing capitalism. You can see this already in the sociological theories of Max Weber: modern history, he says, has been a long process of rationalization, the rationalization of the state in bureaucratic organization and the rationalization of the economy in industrial capitalism. The effect of this process-the progress of reason and freedom associated with the Enlightenment-has been to liberate humanity from traditional constraints; but at the same time, rationalization produces and disguises a new oppression, the "iron cage" of modern organizational forms. The paradoxical implication here is that capitalism and bu- 
reaucratic domination are just natural extensions of the progress of reason and freedom. In Weber's theory, we can already see one of the characteristic paradoxes of today's postmodernism: in anti-modernism there is often no great distance between lament and celebration.

Modernity and the "Enlightenment Project"

I've suggested that the conflation of capitalism with modernity has the effect of disguising the specificity of capitalism, if not conceptualizing it away altogether. My point, however, is not just that capitalism is historically specific. The other side of the coin is that, if this so-called modernity does not have much to do with capitalism, then the identification of capitalism with modernity may disguise the specificity of modernity too.

I'll illustrate what I mean by going straight to the fountainhead of this so-called modernity, the Enlightenment. Here, again, are some of the main features of modernity that are supposed to go back to the Enlightenment: rationalism and an obsession with rational planning, a fondness for "totalizing" views of the world, the standardization of knowledge, universalism-a belief in universal truths and values-and a belief in linear progress, especially the progress of reason and freedom. These features are supposed to be associated with the development of capitalism, either because early capitalism, in the process of unfolding itself, created them, or because the advancement of these principles, such as rationalization, brought capitalism with it.

As we all know, it has become the height of fashion to attack the so-called Enlightenment project. These Enlightenment values I have just been enumerating are supposed to be-and here I will quote one of the milder indictments-"at the root of the disasters that have racked humanity throughout this century,"4 everything from world wars and imperialism to ecological destruction. There's no space here to go into all the nonsense that is spouted these days about the Enlightenment. So I'll just make one simple point: the conflation of 
"modernity" with capitalism encourages us to throw out the baby with the bath water, or, more precisely, to keep the bath water and throw out the baby.

Postmodernists are inviting us to jettison all that is best in the Enlightenment project-especially its commitment to a universal human emancipation-and asking us to blame these values for the destructive effects we should be ascribing to capitalism. Marxist theorists of postmodernity like Harvey and Jameson generally do not fall into this trap, but their periodization does not help much to avoid it. What I want to suggest here is that it might be useful to separate out the Enlightenment project from those aspects of our current condition that overwhelmingly belong not to the "project of modernity" but to capitalism. This might, by the way, be useful not just in countering anti-Enlightenment postmodernism but also capitalist triumphalism (though maybe they come down to the same thing). Anyway, the obvious way to start is to look at the question historically.

My own argument, to put it baldly, is that much of the Enlightenment project belongs to a distinctly non-capitalist society, not just pre-capitalist but non-capitalist. Many features of the Enlightenment, in other words, are rooted in non-capitalistsocial property relations. They belong to a social form which, I think, is not just a transitional point on the way to capitalism but an alternative route out of feudalism.

I'll try to give you a quick sampling of the kind of thing I have in mind. First, a quick sketch of the relevant historical context: the absolutist state in eighteenth century France. The main thing about the French absolutist state was that it functioned not just as a political form but as an economic resource for a substantial section of the ruling class. In that sense, it represents not just the political but the economic or material context of the Enlightenment. The absolutist state was a centralized instrument of extra-economic surplus extraction, and office in the state was a form of property that gave its possessors access to peasant-produced surpluses. There also were other, decentralized forms of extra-economic appropriation, the residues of feudalism and its so-called "parcellized 
sovereignties." These forms of extra-economic appropriation were, in other words, directly antithetical to the purely economic form of capitalist exploitation.

Now think about the fact that the principal home of the so-called project of modernity, eighteenth century France, is a predominantly rural society, with a limited and fragmented internal market, which still operates on non-capitalist principles, not the appropriation of surplus value from commodified labor-power, not the creation of value in production, but rather the age-old practices of commercial profit-taking-profit on alienation, buying cheap and selling dear, trading typically in luxury goods or supplying the statewith an overwhelmingly peasant population that is the antithesis of a mass consumer market. As for the bourgeoisie, which is supposed to be the main material source, so to speak, of the Enlightenment, it is not a capitalist class. In fact, it is not, for the most part, even a traditional commercial class. The main bourgeois actors here, and later in the French Revolution, are professionals, office-holders, and intellectuals. Their quarrel with the aristocracy has little to do with liberating capitalism from the fetters of feudalism.

So where are the principles of so-called modernity coming from? Are they coming out of a new but growing capitalism? Do they represent an aspiring capitalist class struggling against a feudal aristocracy? Can we at least say that capitalism is the unintended consequence of the project of modernity? Or does that project represent something different?

Consider the class interests of the French bourgeoisie. One way of focusing on them is to project forward to the French Revolution, the culmination of the Enlightenment project. What were the main revolutionary objectives of the bourgeoisie? At the core of their program were civil equality, the attack on privilege, and a demand for "careers open to talent." This meant, for example, equal access to the highest state offices, which the aristocracy tended to monopolize and were threatening to close off altogether. It also meant a more equitable system of taxation, so that the burden would not be disproportionately carried by the Third Estate for the benefit 
of the privileged estates, among whose most cherished privileges were exemptions from taxation. The main targets of these complaints were the aristocracy and the Church.

So how did these bourgeois interests express themselves ideologically? Take the example of universalism, the belief in certain universal principles that apply to humanity in general in all times and places. Universalism has certainly had a long history in the West, but it had a very special meaning and salience for the French bourgeoisie. To put it briefly, the bourgeois challenge to privilege and the privileged estates, the nobility and the Church, expressed itself in asserting universalism against aristocratic particularism. The bourgeoisie challenged the aristocracy by invoking the universal principles of citizenship, civic equality, and the "nation," a universalistic identity which transcended particular and exclusive identities of kinship, tribe, village, status, estate, or class.

In other words, universality was opposed to privilege in its literal meaning as a special or private law-universality as against differential privilege and prescriptive right. It was a fairly easy step from challenging traditional privilege and prescriptive right to attacking the principles of custom and tradition in general. This kind of challenge easily became a theory of history, where the bourgeoisie and its organic intellectuals were assigned a leading role as the historic agents of a rupture with the past, the embodiments of reason and freedom, the vanguard of progress.

As for the bourgeois attitude toward the absolutist state, it's somewhat more ambiguous. As long as the bourgeoisie had reasonable access to lucrative state careers, the monarchical state suited it just fine; and even later, it was the so-called bourgeois revolution that completed the centralizing project of absolutism. In fact, in some ways the bourgeois challenge to the traditional order was simply extending rather than repudiating absolutist principles.

Take, again, the principle of universality. The monarchical state even in the sixteenth century had challenged the feudal claims of the nobility-often with the support of the 
Third Estate and the bourgeoisie in particular-precisely by claiming to represent universality against the particularity of the nobility and other competing jurisdictions. The bourgeoisie also inherited and extended other absolutist principles: the preoccupation with rational planning and standardization, for example, something pioneered by the absolutist state and its leading officials, like Richelieu and Colbert. After all, even the standardization of the French language was part of the state's centralizing project-a project of "rationalization" that had its classic cultural expression in the formal gardens at Versailles. ${ }^{5}$

One interesting footnote here: people like David Harvey (and Marshall Berman ${ }^{6}$ ), who have given us some of the most important treatments of modernity and postmodernity, like to emphasize the duality of the modernist consciousness. The modernist sensibility, they say, combines universality and immutability with a sensitivity to ephemerality, contingency, fragmentation. They suggest that this dualism goes back to the Enlightenment. The argument seems to be that the preoccupation with universality and absolute truth was actually an attempt to make sense out of the fleeting, ephemeral, and constantly mobile and changing experience of modern life, which they associate with capitalism.

Berman quotes some passages from Rousseau's New Eloise, as one of the earliest expressions of the modernist sensibility (he calls Rousseau "the archetypal modern voice in the early phase of modernity"7). The most telling passage comes from a letter in which Rousseau's character St. Preux records his reactions on coming to Paris. What Berman sees here is the modernist sense of new possibilities combined with the unease and uncertainty that comes from constant motion, change, and diversity. It is an experience that Berman associates with an early phase of capitalism.

But something rather different occurs to me when I read the words of St. Preux in New Eloise, or even when I read Berman's own account of the "maelstrom" of modern life. Not so much the experience of modern capitalism but the age-old fear and fascination aroused by the city. So much of what 
Rousseau's St. Preux and Marshall Berman himself have to say about the experience of "modern life" could, it seems to me, have been said by the Italian countryman arriving in the ancient city of Rome. It may be significant that the thinker for whom Rousseau himself expresses a special affinity is the Roman philosopher Seneca - and the sensibility of the New Eloisemay indeed have more in common with ancient Stoicism than with capitalist modernism. But in any case, it seems to me no accident that these so-called "modernist" literary tropes-Rousseau's and those of other European writerscome not from a highly urbanized society but from societies with a still overwhelmingly rural population.

My main point is that the ideology of the French bourgeoisie in the eighteenth century had not much to do with capitalism and a lot more to do with struggles over non-capitalist forms of appropriation, conflicts over extraeconomic powers of exploitation. I do not want to reduce the Enlightenment to crude class ideology; but the point is that in this particular historical conjuncture, in distinctly non-capitalist conditions, even bourgeois class ideology took the form of a larger vision of general human emancipation, not just emancipation for the bourgeoisie but for humanity in general. In other words, for all its limitations, this was an emancipatory universalism - which is, of course, why it could be taken up by much more democratic and revolutionary forces.

\section{Modernity vs. Capitalism}

To see the complexities here, all you need to do is compare France with England. England is not generally seen as the main home of "modernity," in the currently fashionable sense of the word, but it certainly is associated with the rise of capitalism. England in the eighteenth century, at the height of "agrarian capitalism," had a growing urban population, which formed a much larger proportion of the total population than in France. Small proprietors were dispossessed, not just by direct coercion but also by economic pressures. Lon- 
don was the largest city in Europe. There was a far more integrated-and competitive-internal market, the first national market in Europe or the world. There already existed the beginning of a mass consumer market for cheap everyday goods, especially food and textiles, and an increasingly proletarianized work force. England's productive base in agriculture was already operating on basically capitalist principles, with an aristocracy deeply involved in agrarian capitalism and new forms of commerce. And England was in the process of creating an industrial capitalism.

What, then, are the characteristic and distinctive ideological expressions of English capitalism in the same period? Not Cartesian rationalism and rational planning but the "invisible hand" of classical political economy and the philosophy of British empiricism. Not the formal garden of Versailles but the irregular, apparently unplanned and "natural," landscape garden. Certainly there was an interest in science and technology. After all, the French Enlightenment owed much to people like Bacon and Locke. But here in England, the characteristic ideology, that which set it apart from other European cultures, was above all the ideology of "improvement"-not the Enlightenment idea of the improvement of humanity but the improvement of property, the ethic - and indeed the science - of productivity and profit, the commitment to increasing the productivity of labor, the ethic of enclosure and dispossession.

The idea of improvement and productivity in this sense goes back to the seventeenth century and had its earliest theoretical expression in the political economist, William Petty, and in John Locke. This ideology, especially the notion of agricultural improvement and the improvement literature produced in England, is conspicuously absent in France at the same time, where peasants dominate production and landlords retain their rentier mentality-as, for that matter, does the bourgeoisie on the whole. The exception here, by the way, proves the rule: in particular, the Physiocrats, those French political economists for whom English agriculture was the model. 
Now if you want to look for the roots of a destructive "modernity"-the ideology, say, of technocentrism and ecological degradation - you might start by looking here, not in the Enlightenment but in the project of "improvement," the subordination of all human values to productivity and profit. Dare I say that it's no accident that the mad cow disease scandal has happened in Britain, the birth-place of "improvement," and not elsewhere in Europe?

\section{An Epochal Shift?}

So much for modernity. Now let me get back to the larger question of periodization and to the shift from modernity to postmodernity. I've tried to situate modernity in a particular conception of history that I think is deeply flawed, that I think has the effect of obscuring the historical specificity of capitalism, and neutralizing or naturalizing capitalism, if not actually conceptualizing it out of existence.

However, we still have to deal with the changes in capitalism. We all know that capitalism by definition means constant change and development, not to mention cyclical crises. But was there a historic rupture of some special kindmaybe in the 1960s or 1970s?

I have to tell you right away that I am only beginning to clarify my thoughts on this. The one thing I am pretty sure about is that the concepts of modernity and postmodernity, and the periodization of capitalism in these terms, will not help us understand whether there has been some historic rupture, and if there has, what exactly it is, how deep it is, how lasting and decisive, or what consequences it might have for any political project. These concepts and this periodization invite us, I think, to look in all the wrong places.

I've been saying here that the concept of modernity as it is currently used is associated with a view of capitalist development that combines technological determinism with commercial inevitability, so that capitalism is simply an extension of certain transhistorical, almost natural processes: the expansion of trade and technological progress. What kind of 
periodization of capitalism would we expect from this kind of view? What would be the sign-posts of major epochal change? You might expect the milestones to mark some major change in the market and/or some major technological shift. That is, in fact, pretty much what you do get in current theories of the transition from modernity to postmodernity. And while these theories may tell us many interesting things, I'm not sure they tell us very much about any major historical ruptures in capitalism.

Take the so-called transition from Fordism to flexible accumulation. I'll leave aside the question of how widespread these changes in the labor-process and marketing strategies actually are. But I've been asking myself what exactly is new about this shift. I don't mean there's nothing new. But what is so new that it justifies talking about an epochal transition from modernity to postmodernity, and even from the whole of capitalism up to that point to some really new kind of capitalism?

The old Fordism used the assembly line as a substitute for higher-cost skilled craftsmen and to tighten the control of the labor-process by capital, with the obvious objective of extracting more value from labor. Now, the new technologies are used to the same ends: to make products easy and cheap to assemble (how else, by the way, would outsourcing, and so on be possible?), to control the labor-process, to eliminate or combine various skills in both manufacturing and service sectors, to replace higher with lower-wage workers, to "downsize" workers altogether-again, to extract more value from labor. So what is new about this so-called new economy is not that the new technologies represent a unique kind of epochal shift. On the contrary, they simply allow the logic of the old mass production economy to be diversified and extended. Now, the old logic can reach into whole new sectors, and it can affect types of workers more or less untouched before.

To see these developments as a major epochal rupture, you have to focus on the more or less autonomous logic of technology, whether it is the technology of the labor process or the technology of marketing. My emphasis here is on the 
logic of capitalism, not some particular technology or laborprocess but the logic of specific social property relations. There certainly have been constant technological changes and changes in marketing strategies. But these changes do not constitute a major epochal shift in capitalism's laws of motion.

Or maybe we could say that Fordism itself did constitute some kind of epochal shift, at least in the sense that it represented the completion of the process that Marx called the real, as distinct from the formal, subsumption of labor by capital. In that sense, the new technologies do not represent an epochal shift so much as an extension of Fordism. What I mean here is not just that the logic of capitalist accumulation still applies in some general sense to the new technologies or to new forms of production and marketing, but that they are following the logic of Fordism in particular.

So What is New?

On the whole, I'm inclined to dismiss the "condition of postmodernity" as not so much a historical condition corresponding to a period of capitalism but as a psychological condition corresponding to a period in the biography of the Western left intelligentsia. It certainly has something to do with capitalism, but it may just be the theoretical self-consciousness of a generation of intellectuals who came to maturity in the atypical moment of the long post-war boom. For some in this generation, the end of the boom felt like the end of normality, and so the cyclical decline since the $1970 \mathrm{~s}$ has had a special, cataclysmic meaning for them. Others, especially "postmodern ists," still seem to be stuck in the prosperous phase of so-called consumer capitalism.

If there has been some special kind of epochal change in the latter half of the twentieth century, we have to look for it somewhere else. If we are looking for transformations more profound than changes in technology or marketing strategies, then explanations having to do with flexible accumulation or consumerism just aren't good enough. If there has been an epochal shift in the latter half of the twentieth century, we're 
going to have to look for it somewhere other than in flexible accumulation, consumerism, information technology, the culture of postmodernism, or any of the usual suspects. Eric Hobsbawm, in his recent history of the twentieth century, talks about a monumental change in the mid-twentieth century, in fact what he calls "the greatest, most rapid, and most fundamental [economic, social, and cultural transformation] in recorded history." Its most dramatic symptom, he suggests, has been the death of the peasantry. But what underlies this change, I think, is that this is the period when capitalism itself has become for the first time something approaching a universal system.

I mean that capitalism, even in so-called advanced capitalist societies, has for the first time truly penetrated every aspect of life; the state, the practices and ideologies of ruling and producing classes, and the prevailing culture. In my book, The Pristine Culture of Capitalism and elsewhere, I've suggested some of the ways in which even in Western Europe (and contrary to some conventions, more in Continental Europe than in Britain), capitalism has been slow to absorb the state and the dominant culture; but in the past few decades, you could say the process has been all but completed. And, of course, in this same period capitalism was also becoming a truly global phenomenon. But let me hasten to add that I don't mean by this what is generally meant by that tired old formula, "globalization." I'm not talking here just about the growth of multinational corporations or about the weakness of the nation-state--both of which I have my doubts about. I'm talking here about the universalization of capitalism itself, its social relations, its laws of motion, its contradictions--the logic of commodification, accumulation, and profit-maximization penetrating every aspect of our lives.

If we've been seeing something new since the 1970s, it's not a major discontinuity in capitalism but, on the contrary, capitalism itself reaching maturity. It may be that we're seeing the first real effects of capitalism as a comprehensive system. We're seeing the consequences of capitalism as a system not only without effective rivals but also with no real escape routes. Capitalism is living alone with its own internal contradictions. It 
has little recourse outside its own internal mechanisms to correct or compensate for those contradictions and their destructive effects. Even imperialism, which was supposed to be the last refuge of capitalism, just ain't what it used to be: in the old forms of territorial or colonial imperialism, capitalist powers used to play out their rivalries and contradictions on non-capitalist terrain. Now even this corrective mechanism has for the most part been replaced by purely capitalist mechanisms of economic domination and financial imperialism.

So this isn't just a phase of capitalism. This is capitalism. If "modernity" has anything at all to do with it, then modernity is well and truly over, not created but destroyed by capitalism. The Enlightenment is dead. Maybe socialism will revive it, but for now the culture of "improvement" reigns supreme. And if that's what the story is about, we don't really need the idea of postmodernity. The only concept we need to deal with this new reality is capitalism. The antithesis to that, of course, isn't postmodernism but socialism. So if what I'm suggesting is right, then the universality of capitalism is not grounds for abandoning the socialist project, as capitalist triumphalists would like to believe. On the contrary, the "totalization" of capitalism also means its increasing vulnerability to its own internal contradictions and to oppositional politics.

Recently I heard Daniel Singer talking about an interesting coincidence. Not long ago, he said, the French ruling classes began to congratulate themselves on finally turning France into a "normal" country-that is, a modern capitalist society. This was, for instance, one of the main themes at the funeral of Mitterrand, the major architect of French "normality" who had moved France in the direction of the neo-conservative governments elsewhere in Europe and the United States. Yet at this very moment of self-congratulation, the French people took to the streets, in some places in unprecedented numbers. That, I guess, was the effect of directly confronting capitalism without decoration or refinement, in all its stark and unadorned reality. Let us hope it was also a symptom of a real epochal shift. 


\section{NOTES}

1. See, for example, Fredric Jameson "Five Theses on Actually Existing Marxism," Monthly Review 47, no. 11 (May 1996); and David Harvey, The Condition of Postmodernity (Oxford and Cambridge, Mass., 1990).

2. For the theory of "disorganized capitalism," see S. Lash and J. Urry, The End of Organized Capitalism (Madison, WI: University of Wisconsin Press, 1987).

3. I have developed some of the arguments in this section in "From Opportunity to Imperative: The History of the Market," Monthly Review 46 no, 3 (July/August 1994).

4. Roger Burbach, "For a Zapatista Style Postmodernist Perspective," Monthly Review 47 no. 10 (March 1996): 37.

5. I have discussed some of the points in this paragraph at greater length in The Pristine Culture of Capitalism: A Historical Essay on Old Regimes and Modern States (London: Verso, 1991).

6. Marshall Berman, All That is Solid Melts into Air: The Experience of Modernity (New York: Penguin Books, 1988).

7. Ibid., p. 18.

8. Eric Hobsbawm, The Age of Extremes: A History of the World, 1914-1991 (New York: Pantheon, 1994), pp. 8, 289.

\section{Subscribe please!}

口 \$28 one-year (U.S.)

$\$ 36$ one-year (foreign)

Name

Address

City/State/Zip

\section{MONTHLY REVIEW}

\section{West 27th St. New York. NY lomol}

